\title{
Formation of an approach to assessing the energy efficiency class of an industrial facility
}

\author{
Tatiana Meshcheryakova* \\ Moscow State University of Civil Engineering, Yaroslavskoe shosse, 26, Moscow, 129337, Russia
}

\begin{abstract}
Analysis of the world practice in the field of classification of various objects of assessment, allows us to conclude that there are different approaches to organizing a certain set of objects under study in accordance with the established signs or criteria. In the course of the implementation of a scientific project to develop a methodology for assessing energy efficiency classes of industrial facilities, a methodology for choosing an approach to the classification of industrial facilities is proposed. The proposed research methodology is based on a comparison of their objective characteristics, features and scope of application, as well as the subjective opinion of experts with experience in standardization and the development of methodic classification of objects by the level of energy efficiency in accordance with the principles of sustainable development. The result of the study will be the ranking of industrial facilities according to the developed ranking system. This will make it possible to form a system for benchmarking the energy efficiency of industrial facilities and will become a tool for stimulating energy management at enterprises.
\end{abstract}

\section{Introduction}

Industry in Russia is the largest end consumer of energy resources, in contrast to most economically developed countries, where the residential sector of the economy is in the first place. This fact is confirmed by the data of national energy balances. The significance of the topic of the research topic has been determined at the state level for more than a decade. The existing potential for energy saving in industry has not yet been realized to the extent possible, due to the lack of effective tools in the field of diagnostics of the energy efficiency of industrial facilities, as a category that is not commensurate only with production facilities or with a production building as a real estate object.

The analysis of the world practice of monitoring the energy consumption of the industrial sector of the economy showed that currently there is no real toolkit for assessing the level of energy efficiency of industrial facilities, both in Russia and abroad.

The aim of the study is to determine an effective approach to the classification of industrial facilities by the level of energy efficiency.

The object of research is industrial facilities as a category for assessing the level of energy efficiency.

\footnotetext{
*Corresponding author: meshcheryakovats@mgsu.ru
} 
The subject of the research is the formation of a methodology for choosing the principles and criteria for assessing the energy efficiency of industrial facilities.

Research objectives set and solved during the research:

- analysis of methodologies for the classification of various objects, their objective features and scope;

- Carrying out a survey of experts on the choice of approaches to the classification of industrial facilities by the level of energy efficiency and the definition of the ranking system;

- formulation of a reasonable hypothesis on the scientific approach to the assessment of energy efficiency classes of industrial facilities;

- determination of restrictions on the application of the system of classification of industrial facilities by the level of energy efficiency.

\section{Materials and Methods}

The study used general scientific methods:

- Methods of formalization. This method made it possible to provide a characteristic of the research contour by describing the properties of an industrial facility as a complex category of analysis, based on theoretical information.

- Hypothetical-deductive. This method determined the formation of an integral system of hypotheses, on the basis of which it is possible to draw some general conclusion concerning a specific subject of research. Each of the considered approaches to assessing energy efficiency classes of industrial facilities are the basis of hypotheses

- Empirical general scientific methods are used when questioning experts and interviewing in the subject area of research. Their entire totality: observation, description, measurement, experiment, comparison, will also form the basis for the implementation of the final stage of a scientific project, which makes it possible to conduct a survey of managers and their proxies, competent representatives from industrial enterprises (chief power engineers and / or authorized technical specialists), taking into account the preliminary received expert opinion on the content of the survey.

As part of the formation of the elements of the research methodology, a model was developed that reflects the concept of determining an approach to the classification of industrial facilities by the level of energy efficiency (Fig. 1). 


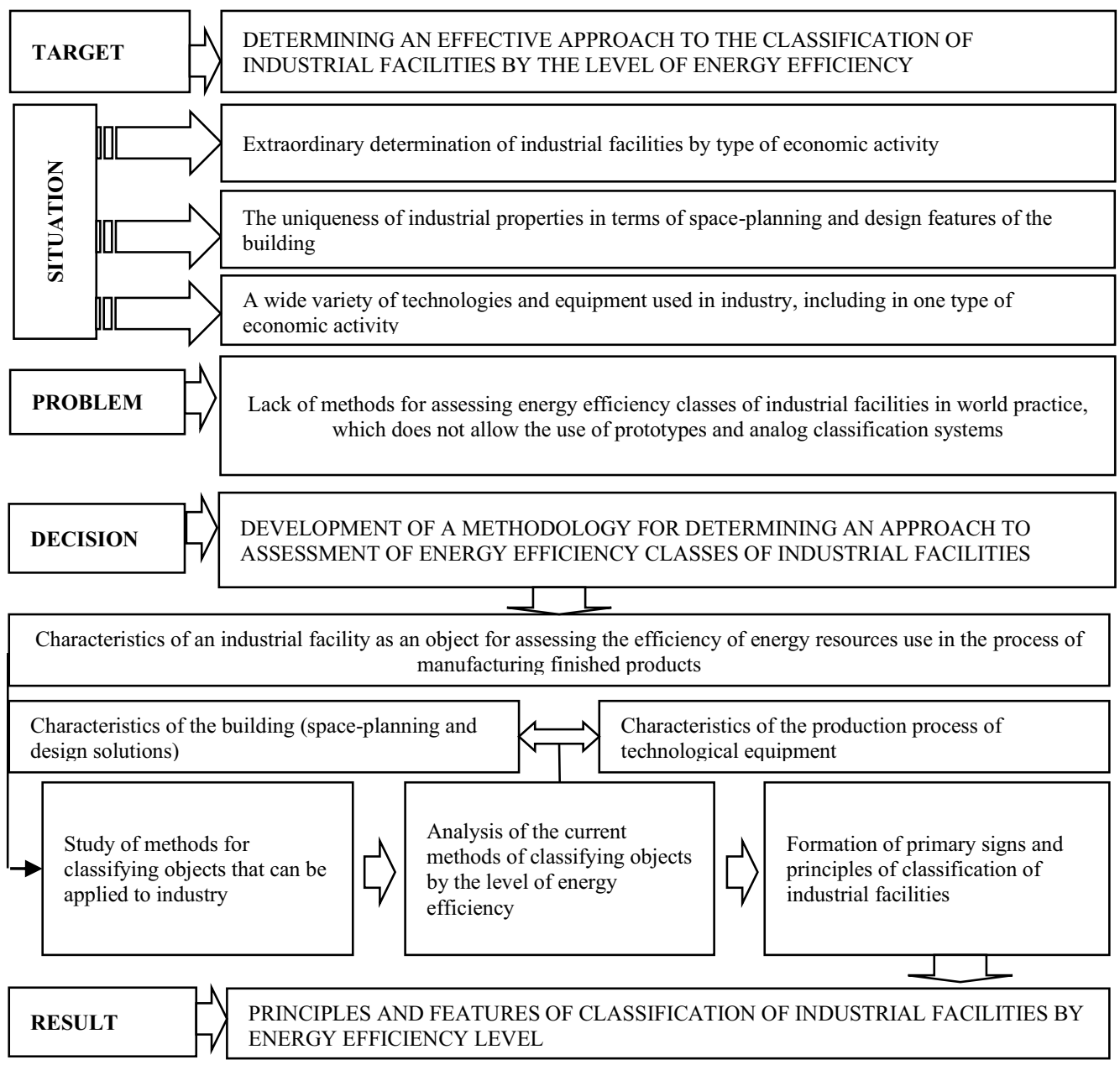

Fig. 1. Scheme for determining the approach to the classification of industrial facilities by the level of energy efficiency.

The above scheme made it possible to conduct a comprehensive study and ensure the maximum objectivity of the proposed solutions to the determination of approaches to the classification of industrial facilities by the level of energy efficiency.

\section{Results}

When analyzing the methodologies for the development of classifications of industrial objects, taking into account the subject area of research, a choice of two most appropriate approaches is proposed: - the formation of a single specific indicator; - drawing up a rating assessment system.

The first option (assessment of the specific indicator) can be based on the calculation of one of the following alternative indicators, taking into account the standardized efficiency of the equipment:

- energy intensity - the total amount of consumption of all types of energy and fuel (direct, indirect, materialized) for the production of a unit of production in accordance with current 
technologies (consumption of energy resources in thousand tons of tons / volume of production in monetary terms);

- the share of payments for energy resources in the value of manufactured products (\%).

The second option (rating score) is defined as an individual numerical indicator for assessing the work of an organization, which makes it possible to assess the effectiveness of its social, industrial, economic activities among other, similar organizations (also organizations at the same management level), or to determine the position of this organization in the general classification of a single a system that includes a level hierarchy of their activities. The rating assessment may include: the method of sums, the method of geometric mean, the method of coefficients, the method of distances, calculation by the formula of the Euclidean distance, the method of two-dimensional scaling and others. In practice, the above rating assessment methods may have modifications.

The preliminary mechanism for the development of directions or sections of the methodology for assessing energy efficiency classes of industrial facilities includes the determination of the object, assessment from the point of view of the real estate object and the technological process that provides the production of the basis of the product (Fig. 2).

Assessment object

\begin{tabular}{|c|c|c|}
\hline Building & Rational water use & \\
\hline $\begin{array}{l}\text { Solutions: } \\
\text { - Architectural } \\
\text { - Constructive } \\
\text { - Biophysical } \\
\text { - Organizational }\end{array}$ & 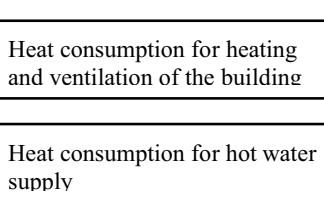 & $\begin{array}{l}\text { Comparative and calculated method. } \\
\text { Percentage expression of the difference between } \\
\text { the specific design (actual) and base value of the } \\
\text { heat energy carrier consumption. Data of project } \\
\text { documentation or energy passport of the } \\
\text { building; actual data of the operating } \\
\text { organization. }\end{array}$ \\
\hline & Power consumption & \\
\hline
\end{tabular}

\begin{tabular}{|c|c|c|}
\hline \multirow[t]{3}{*}{$\begin{array}{l}\text { Technological } \\
\text { process }\end{array}$} & $\begin{array}{l}\begin{array}{l}\text { Energy efficiency of process } \\
\text { equipment }\end{array} \\
\begin{array}{l}\text { Energy efficiency of } \\
\text { production }\end{array}\end{array}$ & $\begin{array}{l}\text { Comparative analysis and calculation method. } \\
\text { Equipment labeling data; conformity assessment } \\
\text { of the actual characteristics to the marked ones in } \\
\text { the presence of technical documentation. Primary } \\
\text { diagnostics of energy consumption (in the } \\
\text { absence of marking). }\end{array}$ \\
\hline & $\begin{array}{l}\text { Share of payments for energy } \\
\text { resources in the value of } \\
\text { manufactured products (\%) }\end{array}$ & \multirow{2}{*}{$\begin{array}{l}\text { Calculated valuation method. } \\
\text { Data of project documentation or energy passpor } \\
\text { of the building; actual data of the operating } \\
\text { organization. }\end{array}$} \\
\hline & $\begin{array}{l}\text { Energy intensity (consumption } \\
\text { of energy resources in } \\
\text { thousand tons of standard fuel / } \\
\text { volume of production in } \\
\text { monetary terms) }\end{array}$ & \\
\hline
\end{tabular}

$\begin{aligned} & \text { Management } \\ & \text { (administration } \\ & \text { level) of energy } \\ & \text { policy }\end{aligned}$

Benchmarking, expert assessment method. Analysis of the implementation of a formal or documented energy strategy, energy policy, specialized administrative apparatus in the field of energy saving and energy efficiency in the structure of an enterprise.

Fig. 2. Fragment of sections of mathematics for assessing energy efficiency classes of industrial facilities.

Taking into account the analysis of the most common ranking methods in the field of energy efficiency, it is proposed to use the method of coefficients. This method is based on 
obtaining an integral indicator of the multiplication mechanism of the corresponding coefficients, it is similar to the geometric shape method.

When forming the coefficients, it is advisable to take into account the significance of individual areas of assessment and the weight of groups of indicators with possible adjustment by regions of the country, taking into account climatic factors and resource potential $[1,2,3]$.

\section{Discussion}

At the moment, the declaration of high indicators of energy efficiency of industrial facilities is not an integral part of the company's image and, ultimately, the implementation of an energy efficient policy always comes down to a direct economic benefit.

The most important problem, the solution of which can significantly change the approach of an industrial enterprise to the implementation of economic activities with target energy efficiency indicators, is the creation of a methodology for assessing the energy efficiency class of an industrial facility. Energy efficiency classes are set only for industrial equipment. There are also different approaches to assessing the environmental friendliness and energy efficiency of buildings according to Russian and international "green" standards (LEED, BREEAM, DGNB). However, energy consumption in industry in most cases is associated not with the characteristics of the real estate object, but with the operated industrial equipment, which excludes the possibility of using the category of an industrial facility defined in the field of architecture and construction according to standard spaceplanning and structural solutions $[4,5]$.

Considering the methods of diagnostics of industrial facilities, it should be noted that they can be documentary and instrumental, and for obtaining reliable information, their applied system combination is certainly important. These techniques are used for certification of survey objects and identification of their energy saving potential.

On the basis of the available opportunities for a comprehensive increase in the energy efficiency of industrial facilities, it is proposed to use the accumulated scientific and practical material in this area and apply the following fundamental indicators for diagnostics, which are traditionally reflected in the energy passport: - the range of the main products; - volume of production (monetary equivalent); - production of products in kind, total (pieces); - consumption of energy resources, total (thousand tons of standard fuel); energy intensity of production, total (consumption of energy resources in thousand tons of standard fuel / volume of production in monetary terms); - the share of payments for energy resources in the value of manufactured products (\%); - total capacity of electrical receivers (permitted installed and average annual declared (thousand $\mathrm{kW}$ ); - values of efficiency $(\mathrm{COP})$ and fuel use (FU) of production equipment used for main production and auxiliary processes.

Among the most advanced national rating systems, the American one should be noted LEED, BREEAM, DGNB [1, 2].

Rating systems allow assigning an assessment to a project, expressed in the sum of points for a number of priority areas that characterize design solutions.

The number of areas assessed and their weight is determined by national priorities and the system of rationing.

When assigning an assessment of the weight of the criteria, priority was given to energy efficiency indicators for the following reasons:

- energy efficiency indicators are directly related to environmental criteria, since saving heat and electricity leads to a decrease in emissions of harmful components into the 
atmosphere in combustion products from energy sources - carbon dioxide and oxide, nitrogen oxides, sulfur compounds [6-11];

- given the significant potential for energy saving in buildings, the priority of energy efficiency implies an accelerated overcoming of the gap in this indicator from the technically developed countries $[6,12,13]$.

Depending on the number of points summed up in the analysis of the project, it is assigned an energy and environmental efficiency class.

This rating system is convenient to use as the simplest prototype when drawing up a methodology for assessing the energy efficiency of industrial facilities. The resulting classification system will be understandable by the overwhelming number of users and applicable in the international space.

An interview with leading experts in the subject area of the study also confirmed the hypothesis about the preference of developing a rating system for assessing the energy efficiency class of an industrial facility.

At the moment, the scientific discussion is related to determining the need to include in the methodology for assessing the level of energy efficiency of industrial facilities the characteristics of production sites associated with the microclimate of the premises.

\section{Conclusion}

To overcome the existing barriers to increasing the energy efficiency of industry, through the use of the proposed diagnostic tools and the development of new methods for diagnosing the energy efficiency of industrial facilities, it is necessary, first of all, to create a unified information statistical base of industrial facilities (EISB) in the context of their identification and classification, taking into account the types of economic activities in accordance with groups of OKVED-2. Monitoring of indicators of energy consumption of industrial facilities should be systematic and carried out with the assistance of the main competent authority responsible for the implementation of energy efficient state policy - the Ministry of Economic Development of the Russian Federation. The formation of a single coordinated decomposition model for managing the energy efficiency of industrial facilities will become the most important prerequisite for increasing the use of innovative energysaving measures and the use of updated best available technologies (BAT) that can reduce the energy intensity of GDP.

When implementing the developed rating system, it is planned to define an umbrella standard that limits the area of application of the methodology for assessing energy efficiency classes of industrial facilities.

The reported study was funded by RFBR project number 20-010-0075.

\section{References}

1. A.Yu. Tabunshchikov, V.V. Granev, A.L. Naumov, Rejtingovaya sistema ocenki kachestva zdanij, Indoor microclimate [Rating system for assessing the quality of buildings], AVOK-PRESS LLC, 6 (2010)

2. NATIONAL ASSOCIATION OF BUILDERS, STO NOSTROY 2.35.4-2011 Standart organizacii «Zelenoe stroitel'stvo» ZDANIYA ZHILYE I OBSHCHESTVENNYE. Rejtingovaya sistema ocenki ustojchivosti sredy obitaniya [STO NOSTROY 2.35.42011 Green Building Organization Standard RESIDENTIAL AND PUBLIC BUILDINGS. Habitat sustainability rating system], AVOK-PRESS LLC, Moscow, 2011 
3. NATIONAL ASSOCIATION OF BUILDERS, STO NOSTROY 2.35.68-2012 ZDANIYA ZHILYE I OBSHCHESTVENNYE Uchet regional'nyh osobennostej $v$ rejtingovoj sisteme ocenki ustojchivosti sredy obitaniya [RESIDENTIAL AND PUBLIC BUILDINGS Taking into account regional peculiarities in the rating environmental sustainability assessment system], AVOK-PRESS LLC, Moscow, 2012

4. Bashmakov Ispolzovanie benchmarkinga I kalkulyatorov pri ocenke potenciala energosberezheniya $v$ zdaniyah [Use of benchmarking and calculators in express assessments of energy saving potential in buildings], AVOK-PRESS LLC, 1 (2021)

5. A.A. Fisenko, M.E. Basse, Energoeffektivnost' promyshlennoj arhitektury: sovremennaya teoriya i praktika [Energy efficiency of industrial architecture: modern theory and practice]. Architecture and modern information technology, 2013, AMIT 2 (23) (2013)

6. World Energy Outlook 2020 International Energy Agency, October 2020, France (2020)

7. Government of the Russian Federation, Postanovlenie o sostave razdelov proektnoj dokumentacii i trebovaniyah $k$ ih soderzhaniyu [Resolution on the composition of the sections of the project documentation and the requirements for their content] December 21, JSC "Codex", 2020

8. Fernando Castro-Alvarez, Shruti Vaidyanathan, Hannah Bastian, and Jen King, The 2018 International Energy Efficiency Scorecard (American Council for an EnergyEfficient Economy, Washington, 2018)

9. United Nations economic commission for Europe Joint Task Force on Energy Efficiency Standards in Buildings, Mapping of Existing Energy Efficiency Standards and Technologies in Buildings in the UNECE Region (UNECE, Geneva, 2018)

10. European Commission, GOOD PRACTICE IN ENERGY EFFICIENCY For a sustainable, safer and more competitive Europe (EU, Brussels, 2017)

11. United Nations economic commission for Europe, Promoting Energy Efficiency Standards and Technologies to Enhance Energy Efficiency in Buildings (UNECE, Geneva, 2020)

12. S. Lee, M. Taniguchi, N. Masuhara, R.H. Mohtar, S.-H. Yoo, M. Haraguchi, Analysis of industrial water-energy-labor nexus zones for economic and resource-based impact $169, \mathbf{1 0 5 4 8 3}(2021)$

13. K.L. Urban, F. Scheller, T. Bruckner, Suitability assessment of models in the industrial energy system design 137, 110400 (2021) 